sciendo Порівняльна професійна педагогіка 9(1)/2019 Comparative Professional Pedagogy 9(1)/2019

DOI: $10.2478 /$ rpp-2019-0002

Postdoctoral Researcher of Pedagogy, Full Professor, NINA ZHURAVSKA

National University of Life and Environmental Sciences of Ukraine Address: 16-a Heroyiv Oborony St., Kyiv, 03041, Ukraine E-mail: juravska@ukr.net

\title{
METHODOLOGICAL APPROACHES TO CONSTRUCTING A DIDACTIC MODEL OF SPECIALIST COURSES: COMPARATIVE ASPECT
}

\begin{abstract}
The article analyzes methodological approaches to constructing a didactic model of specialist courses in Ukraine and France. It is found that the main elements of higher education are knowledge, modes of activity (abilities, skills), creative search activities and emotional education. It is specified that knowledge is a system of determined acquired concepts, patterns of phenomena and objects of the objective world. It is clarified that the system of knowledge gained from specialist courses contains the following types of knowledge: scientific (scientific data on which a particular course is based); scientific and historical (the evolution of concepts, ideas and ways of their discovery); methodological (a set of knowledge about science methodology); philosophical, logical and interdisciplinary (the reflection of scientific connections in educational information); evaluative (the description of the individual's relation to the world and his/her system of values). It is stated that the modes of activity are viewed as general scientific, professional and specialist abilities and skills and in terms of psychology - sensory, motor, sensory and motor, intellectual ones. Intellectual skills and abilities include note taking, working with reference literature, writing abstracts and reviews, preparing simple projects (maps, diagrams). It is noted that creative search activities imply a readiness to find solutions to new problems. They also involve applying knowledge and skills in non-standard conditions, considering a new problem under normal conditions, combining well-known modes of activity independently and applying a fundamentally new way of solving the problem. It is highlighted that emotional education is characterized by evaluative knowledge and norms of relation to the world. It is proved that the difference between academic courses and science lies in the fact that it includes only the main principles of one or another field of knowledge within a particular science available for students to acquire.
\end{abstract}

Keywords: methodological approaches, methodology, knowledge, modes of activity, abilities, skills, creative search activities, emotional education.

\footnotetext{
АНОТАЦІЯ

Проаналізовано методологічні підходи до конструювання дидактичної моделі фахових дисциплін в Украйні та Франції. Визначено, що основними елементами вищої освіти є: знання, способи діяльності (уміння, навички), творча пошукова діяльність, емочійно-вольове виховання. Вказано, що знання - че система визначених засвоєних понять, закономірностей про явища, предмети об'єктивного світу. Зазначено, що система знань із фахових дисииплін містить наступні види знань: наукові (дані науки, на якій базується дисиипліна), науково-історичні (еволючія понять, ідей, иляхи відкриття), методологічні (сукупність знань із методології науки), філософські, логічні, міжпредметні
} 
sciendo Порівняльна професійна педагогіка 9(1)/2019 Comparative Professional Pedagogy 9(1)/2019

(відображення в навчальній інформачії між наукових зв'язків), очіночні (фіксують відношення людини до навколишнього світу, його систему иінностей). Вказано, щяо способи діяльності - ие вміння, навички, які є загальнонауковими, професійними, фаховими; з точки зору психології-сенсорними, моторними, сенсорно-моторними, інтелектуальними; до інтелектуальних умінь і навичок належать: конспектування, робота з довідковою літературою, написання тез, рецензій, складання нескладних проектів (карт, схем). Зазначено, щуо творча пошукова діяльність - це готовність до пошуку вирішення нових проблем, завдань. Це застосування знань, умінь у нестандартних умовах, бачення нової проблеми в звичайних умовах, самостійне комбінування відомих способів діяльності, застосування принципово нового способу вирішення завдання. Наголошено, щуо емочійновольове виховання характеризується оціночними знаннями, нормами відношення до світу. Обгрунтовано, щзо відмінність навчальної дисиипліни від науки полягає в тому, щуо до нього входять тільки основні положення тієї чи іншої галузі знань конкретної науки, доступні для засвоєння студентами.

Ключові слова: методологічні підходи, методика, знання, способи діяльності, уміння, навички, творча пошукова діяльність, емочійно-вольове виховання.

\section{INTRODUCTION}

The changes in production are constantly generating non-standard conditions which specialists regularly encounter in the workplace. Therefore, it is very important to teach students to apply their acquired knowledge when solving new problems. The specifics of higher agricultural education institutions consists in the fact that there are the widest opportunities to develop specialized knowledge, abilities and skills which can be applied under the changed conditions. Professional training of agricultural specialists and, in particular, lecturers of specialist courses, is a rather difficult task.

Given that agricultural production is a special kind of creativity in the field of organizing and implementing the production process, only those individuals who have good theoretical and practical training and relevant types of behaviour can actually teach specialist courses. In addition, they must teach those who are endowed by nature with certain personality traits. Indeed, professional training of lecturers of specialist courses can be considered effective provided that the scientific and methodological support of the education process is appropriate and incorporates practical training, including internships abroad. Finally, such training should be based on the relevant legal framework.

\section{THE AIM OF THE STUDY}

The aim of the article is to analyze methodological approaches to constructing a didactic model of specialist courses in Ukraine and France.

\section{THEORETICAL FRAMEWORK AND RESEARCH METHODS}

The methods of scientific knowledge and the development of its methodology were studied by such prominent scholars of the past as Aristotle, F. Bacon, G. Galilei, G. Leibniz, I. Newton et al. The peculiarities of specialists' methodological training were clarified by N. Bidyuk, F. Eisenberg, L. Ferry, P. Ladriere, M. Leshchenko, M. Marzano, O. Matviienko, S. Nikolaienko, N. Zhuravska et al.

In order to achieve the aim of the article, the following research methods were used: analysis and generalization of empirical and theoretical provisions contained in professional and reference literature from various scientific fields, as well as in the studies by prominent Ukrainian and foreign researchers. 
sciendo Порівняльна професійна педагогіка 9(1)/2019 Comparative Professional Pedagogy 9(1)/2019

\section{RESULTS}

The requirements put forward by society for professional training of future specialists pay specific attention to autonomy since one cannot create a single algorithm which can be used to solve all the tasks. One cannot predict all conditions and types of actions which may occur in all production situations. It must be noted that the education process as the basis of any scientific research is rather complex and requires a conceptual approach based on a certain methodology. The term methodology comes from the Greek word "methoges" (cognition) and "logos" (study). Thus, the concept of "methodology" has two meanings: firstly, it is the combination of tools, methods and techniques applied in a particular science; secondly, it is a branch of knowledge which studies means and principles of organizing cognitive and practical activities of individuals. A methodology is a scheme or plan for solving research objectives. When studying concrete methods of conducting experiments, observations or measurements, research methodology distinguishes those features that are inherent in any experiment.

Therefore, the development of methodology is one of the sides of science development in general. Any scientific discovery is characterized not only by substantive but also methodological content since it is related to a critical reconsideration of the existing concepts, preconditions and approaches to interpreting the object under study.

The current research proves that methodology acts as a separate scientific discipline, which studies the technology of conducting scientific research, describes and analyzes research stages and a number of other problems.

A methodology is a set of rules for defining concepts in all branches of science and at all stages of the research. It is a study about the system of scientific principles and methods of research activities. It contains fundamental and general scientific principles (being its basis), specific scientific principles (underlying the theory of this or that discipline or scientific branch), as well as a system of concrete methods and techniques (solving special research tasks).

It must be noted that many foreign scholars, including J. Carbonier and R. Cornuta, do not distinguish between methodology and research methods. Ukrainian scholars, in turn, consider methodology as a study about research methods and as a system of scientific principles on which the research is based and research means, methods and techniques are selected. According to B. Sheiko and N. Kushnarenko, a methodology is a conceptual presentation of the aim, content and methods of research which make it possible to obtain objective, accurate and systematic information about the processes and phenomena under study.

According to French experience, methodology as a science mainly aims to determine the research problem and subject, study and analyze methods, means and techniques through which one can obtain new knowledge both at empirical and theoretical levels and finally, verify the obtained results (Zhuravska, 2015, pp. 51-54).

The current research suggests that one should take into consideration the following functions of methodology when constructing a model of specialists:

- to select methods required to obtain scientific knowledge which reflects dynamic processes and phenomena;

- to select a certain way to achieve the research aim;

- to provide comprehensive information about processes or phenomena under study;

- to introduce new information to the fund of scientific theory;

- to clarify, expand and systematize scientific terms and concepts; 
sciendo Порівняльна професійна педагогіка 9(1)/2019 Comparative Professional Pedagogy 9(1)/2019

- to create a system of scientific information based on objective facts and a logical and analytical toolset of scientific knowledge.

The model of specialists should contain two blocks: the main (content) block which includes the content of the course and the procedural block which ensures the acquisition of knowledge and contributes to shaping scientific outlook, creative thinking, abilities and skills. Specialist courses can have several leading components, namely scientific knowledge and modes of activity, etc. Depending on the leading component, they can be characterized by different content and teaching methodology. It is proved that specialist courses are based on several sciences and are rather complex. This, in turn, determines their structure (Zhuravska, 2006, pp. 18-21). The system of links between the individual components of the course is the subject of research methodology as a science. The system of concepts of biology-oriented courses consists of biological and technological concepts. These concepts are the stage for further development of concepts that have emerged during the study of general academic courses. It must be noted that gnoseological notions (the study about knowledge) are related to biological and technological concepts. The course structure defines goals and objectives.

The author of the research believes that a model is an artificially created object in the form of a scheme and a drawing that reflects and reproduces the structure, quality and interrelations between the elements of the object under study in a reduced form.

Nowadays, there are several models of specialists. They are the following: hypothetical (theoretical); presentative (active specialists); prognostic (forecast for the future). A set of professional competencies can be considered as an example of a hypothetical (theoretical) model. Based on the study of foreign experience (Alquie, 2005; Ferry, 2013; Ladriere, 1991; Marzano, 2008), the current research proposes a presentative model of specialists, in particular a graduate from an agricultural higher education institution: 1. The scope of activity: joint-stock companies, agricultural companies; collective, leasing, contracting, farmer and agricultural enterprises; higher education institutions and research institutions; management of agricultural enterprises. 2. The posts: head of the enterprise; chief specialist, leading specialist, specialist, head of structural unit; manager, senior researcher, faculty member in higher education institutions. 3. Functions: organizational, technological, planning, accounting, forecasting, controlling, management, reporting, research and educational. 4. Professional requirements. 5. Creative activities: regular enhancement of one's professional image; promotion of leadership skills based on self-improvement and self-organization; further development of production training; enhancement of performance effectiveness; active participation in public life. 6. Emotional profile (one's reaction to the surrounding reality and vision of it): discipline, sociability, being good at noticing things, initiative, erudition, high moral qualities; higher expectations for oneself and employees, principality and respect for others; adaptability to market conditions.

The current research proves that the lecturer should possess the following personality traits: discipline, sociability, being good at noticing things, initiative, erudition, high moral qualities; higher expectation for oneself and employees, principality and respect for others, adaptability to market conditions.

P. Ladriere (1991) singles out the following personality traits: responsibility, kindness, devotion to the cause, unquestioning secularism. He also suggests such specialists' duties as respect for departmental policies and programmes, respect for others, non-discrimination, neutrality, awareness. 
According to Aristote (1994), moral requirements determine any action. Unfortunately, the requirements are occasionally controlled by circumstances. Hence, two additional personality traits should be taken into consideration: requirements as a set that constitutes the need and the deep desire of human nature; requirements as a plurality with certain labels: what an individual or community expects from a person; whether this person will meet the requirements: the external constraint which he/she will obey, as well as an internal commitment manifested through the adherence to recognized rules (Alquie, 2005).

The term morality is defined as proper behaviour (acceptable or even exemplary) in this community (Zhuravska, 2015, pp. 38-42). Therefore, moral requirements for the individual include an ideal behaviour to which he/she aspires and the duty which society binds the individual by virtue of a certain recognition (Yashchuk, 2012, pp. 21-22).

P. Ladriere (1991) identifies a fundamental distinction between the two main types of moral requirements: values and standards. Aristote (1990) points out that values are moral requirements expressed positively. Values become forms of great goals, reach ideals, simulate models of proper behaviour. The current research attempts to rank the notion of "value". Specific attention is paid to the expediency of attaching the concept of "lecturer's value" to three main issues:

1. Which personality traits are relevant to you? According to the proposed model of specialists, French scholars offer honesty, generosity, responsibility, loyalty, courage.

2. What lifestyle do you prefer? According to the proposed model of specialists, French scholars suggest the life focused on love, family, friendship and creativity.

3. What kind of society would you build if you had such an opportunity? The examples include the society focused on solidarity, justice and respect for nature.

Thus, French scholars single out the following humanistic values of specialists: respect, autonomy, freedom, dignity, helpfulness, accessibility; adherence to professional qualities, tolerance, competence, loyalty, accessibility, frankness, honesty. They also focus on the values based on the law: discretion, confidentiality, secrecy, respect for individual and collective rights, protection of persons and property.

In the context of the model of specialists, French scholars identify the following democratic values: Republican values (freedom, equality, fraternity), social justice, secularism (distraction from religion as such in society, family, politics, etc.; the principle of secularism based on the reduction of the religion's role in political, social and personal life), citizenship, social cohesion, social utility and general interest.

In their theoretical studies, French scholars define the concept of "standards" as moral requirements expressed in the imperative mode (the imperative method of legal regulation involves organizing the behaviour of the subjects of social relations by its categorical and detailed regulation of legal rules and depriving them of the possibility to establish other rules of conduct). This mode may, among other things, include order, demand combined with a denial, ban.

It must be noted that one pays specific attention to the standards which provide sanctions. The most severe sanctions can be criminal, but there are other less obvious types such as condemnation, indifference, exclusion (Marzano, 2008).

An important role in the model of specialists is played by the norm (Alquie, 2005). French scholars indicate that norms play a vital role in the lives of groups and individuals. They ensure the functions of communication, acculturation (the process of mutual influence of cultures, the perception of one nation in whole or in part of the culture of other peoples) and modelling. They also pay considerable attention to the processes of rupture in 
sciendo Порівняльна професійна педагогіка 9(1)/2019 Comparative Professional Pedagogy 9(1)/2019

standardization processes that operate "blindly" in the centre of professional and institutional practice.

French scholars disclose the concept of "ethics" as a set of proper conduct rules that the profession approves to guide its activities in relation to its mission (Ferry, 2013; Marzano, 2008). However, some scholars note that these rules are not only moral but also technical or legal. The state may consider it necessary to adopt rules of ethics by means of decrees (Yashchuk, 2012, pp. 21-22). As evidenced L. Ferry (2013), every profession can determine its rules. For one, French researchers submit code of ethics for social service assistants, which was developed by L. Anas in 1949 and introduced in 1981 and 1994 (Yashchuk, 2016, pp. 333-339).

Therefore, the specifics of modern higher education consists in the fact that the scientific and technological progress requires that modern graduates should be prepared to navigate under the new conditions of production with which they invariably encounter in the workplace. Indeed, it is very important to teach students to apply their acquired knowledge when solving new problems.

\section{CONCLUSIONS}

Based on the analysis of scientific and reference sources, it is found that it is possible to manage professional training of various specialists on condition that the person's suitability for the education process at different stages of specialization is professionally identified; vocational guidance and early professional selection in schools are organized; relevant conditions for the admission of the selected applicants to higher education institutions are created and their theoretical and practical adaptation to such conditions is ensured; targeted programmes aimed at developing diligence in future specialists are implemented; theoretical training of specialists is combined with practical one due to interdisciplinary connections; creativity is incorporated into the education process.

The analysis of French experience makes it possible to conclude that activitybased approach to constructing the didactic model of specialists taking into account knowledge and skills is achieved through the selection of educational information aimed at professional activities of specialists and the complex of production and pedagogical situations. In the context of activity-based approach, the selection of educational information can occur on the basis of semantic thesaurus approach (based on knowledge) and empirical approach (the quality of practical training: professional and official responsibilities) used to identify the gaps in specialists' knowledge through the content of related educational branches.

\section{REFERENCES}

1. Alquie, F. (2005). La morale de Kant. Retrieved from http://www.gallimard.fr/ Catalogue/Table-Ronde/La-petite-vermillon/Lecons-sur-Kant.

2. Aristote. (1990). Les Politiques. Trad. P. Pellegrin 1990. Paris: GF-Flammarion.

3. Aristote. (1994). Ethique à Nicomaque. Trad. Jules Tricot révisée en 1994. Paris: J. Vrin Poche.

4. Ferry, L. (2013). Une brève histoire de l'éthique. Paris: Flammarion.

5. Ladriere, P. (1991). L'éthique, soi et les autres. Informations sociales, 9, 10-18

6. Marzano, M. (2008). L'éthique appliquée. Paris: PUF. 
sciendo Порівняльна професійна педагогіка 9(1)/2019 Comparative Professional Pedagogy 9(1)/2019

7. Yashchuk, S. P. (2012). Konstitutsionnoe i mezhdunarodnoe pravo: sovershenstvovanie osnovnogo zakona. Suchasni napriamy teoretychnykh i prykladnykh doslidzhen, 18, 21-22.

8. Yashchuk, S. P. (2016). Formuvannia profesiino-pravovoi kompetentnosti studentiv. Naukovyi visnyk Natsionalnoho universytetu bioresursiv i pryrodokorystuvannia Ukrainy. Seriia: Pedahohika, psykholohiia, filosofiia, 253, 333-339.

9. Zhuravska, N. S. (2006). Teoriia i metodyka profesiinoho navchannia. Kyiv: Vydavnychyi tsentr NAU.

10.Zhuravska, N. S. (2015). Metodyka navchannia ta vykhovannia u vyshchykh navchalnykh zakladakh krain Yevropeiskoho Soiuzu ta Ukrainy. Porivnialnyi aspekt. Nizhyn: Lysenko M. M. 